\title{
HISTORICAL AIR PHOTO MISSIONS IN THE MARITIMES DURING THE EARLY 1920s: COVERAGE, THEMATIC SCOPE, AND UTILITY 100 YEARS LATER
}

\author{
DIRK WERLE* \\ Erde Environmental Research, Halifax, NS
}

\begin{abstract}
The historical and technological developments of powered flight and aerial photography have early connections in the Maritimes. Following the Great War (1914-18), a series of pioneering survey missions were initiated by the Canada Air Board in the civilian domain. From a science perspective, the air photos offer a unique opportunity for the detection of environmental change at an unusual centennial time scale. The missions of the early 1920 s initially relied on military surplus seaplanes and innovative camera equipment that yielded several thousand high-resolution vertical air photos. This paper is focussed on the scope and outcome of the first experiments carried out over Nova Scotia and New Brunswick between 1921 and 1925, prior to more systematic use for topographic mapping during the remainder of that decade. The research is based on archival records and partial reconstruction of the digitized air photos into image mosaics. Photo interpretation and comparison with recent high-resolution satellite imagery offer insights concerning land use and land cover changes, coastal dynamics, and transformation of urban, rural and industrial landscapes. Experience todate with these early air photos and mosaics of the Maritimes holds promise for examining similar aerial survey missions in other parts of Canada.
\end{abstract}

\section{INTRODUCTION}

The convergence of powered flight and aerial photography more than a century ago initiated technical and scientific innovation in the practice of surveying and mapping that reverberated throughout the $20^{\text {th }}$ century. The view-from-above, with its ancient connotation of command and privilege, has since extended beyond the exclusive domain of military and civilian authorities. It has become an indispensable tool for surveying and mapping, as well as Earth and environmental sciences. Captured by sophisticated imaging

* Author to whom correspondence should be addressed: dwerle@ca.inter.net 
instruments aboard fleets of airborne and satellite vehicles, aerial views have even entered popular culture through digital networks and online services. A key feature and commonality of both early aerial survey photography and modern high-resolution remote sensing imagery is their vertical perspective; this renders them directly comparable and scalable for unusually long time series, change detection and geospatial analysis concerning local and regional scientific inquiries.

Historically, some of the origins of aerial photography and flight can be traced to pioneering activities in the Maritimes of Canada. In 1882/83 Henry Elsdale, a Captain with the Royal Engineers, successfully captured the first remotely controlled aerial photographs of the Halifax Citadel. He employed a light-weight camera, an automatic timing mechanism, and a small tethered balloon; lacking institutional support, Elsdale used his own funds to conduct the experiments (Elsdale 1884, Werle 2019a). In 1909, Douglas McCurdy piloted the first flight of "Silver Dart", a powered aircraft, at Baddeck in Nova Scotia; the inventor Alexander Graham-Bell and his wife Mabel supported early aeronautical trials and financed them through their Aerial Experimental Association (MacDonald 2017).

Only 10 years after McCurdy's historic flight, aviation and aerial reconnaissance had entered a new phase following the rapid expansion of air forces and air photo know-how during World War 1 under enormous human and financial cost. In Canada, post-war technological and institutional developments relied on veteran personnel and military surplus equipment to apply aerial photography to civilian uses. Size and scope of these activities during the 1920s were small and tentative at first. Under the authority of the newly appointed Canada Air Board, a series of experimental missions were initiated across the country, including the Maritimes (Air Board 1921, 1922; Shaw 2001).

The objective of this study was threefold: 1) (re-)establish a comprehensive record of the aerial survey missions in the Maritimes during the 1920s; 2) determine location, purpose and detail of the actual photography; and 3) assess the potential use of these earliest examples of vertical aerial photography for scientific studies today. Following an outline of the methodological approach and previous work, the location, extent, and thematic scope of seven air survey missions over parts of the Maritimes were examined. This study 
suggests that the century-old photos, especially in aggregate mosaic form, constitute a unique and valuable source of local and regional geospatial information.

\section{STUDY APPROACH}

This study relied on the search, collection and analysis of archival air photos as well as information in the scientific literature and institutional records. Searches concentrated on the Earth Observation Data Management Systems (EODMS) of the Department of Natural Resources Canada and on-site searches at the National Air Photo Library (NAPL) in Ottawa. The work focused on a series of experimental air photo missions initiated by the Canada Air Board (CAB) in the Maritimes during the first half of the 1920s. Annual reports by the Department of National Defence (DND) were reviewed regarding air photo missions conducted during the remainder of the decade. In addition, CAB and DND reports as well as other sources were analyzed to place vertical air photo coverage and its utility for scientific study into the larger regional environmental context. The search for aerial photography cited in this study can be replicated either through public, on-site access at NAPL using flight line index maps and Roll reference numbers, or it can be repeated and extended online through the EODMS. The latter accepts entries of date, location and NAPL Roll reference numbers to render digital air photo footprints and metadata displays and, in a growing number, low-resolution previews of digitized air photos. The NAPL offers both hard copy and digital air photo reproduction services for a fee (www.eodms-sgdot.nrcan-rncan.gc.ca/index_en.jsp).

In terms of technical procedures, this study used individual 300 dot-per-inch scanned NAPL air photos for analysis and annotation and for digital assembly into uncontrolled photo mosaics by fitting them to a suitable reference or remotely sensing image map. Alignments of the road network and features common to both air photos and background map or image served as a guide to geometric fidelity. The individual vertical air photos were arranged sequentially along flight lines and marked with thin frames to emphasize the composite nature of the montage. Once assembled into a mosaic, subsets or individual photos representative of specific analysis topics were compared with recent remote sensing imagery of similar 
spatial detail. This reference imagery was retrieved online through open-access geospatial data platforms, such as Google Earth. Standard photo-interpretation methods were applied to both data sets in order to identify features or areas of interest and assess change.

\section{PREVIOUS WORK}

Previous work on the emergence of aerial photography in Canada during the early 1920s are linked to post-World War I historical accounts of powered flight and its various applications. For this study, primary sources include archival materials and official fiscal year-end reports of the Canada Air Board, the Militia Service, and the Department of National Defence, DND (Air Board 1921, 1922, 1923; DND 1923-1931). They referred to institutional, budgetary and personnel activities as well as equipment and logistical issues, including those connected with the Dartmouth Air Station in the Maritimes. This documentation also reflected the evolution of early aeronautical affairs in Canada. The Air Board served as the first, impermanent, post-World War I governance body for Canadian air defence, civil flying operations and licensing issues. By the mid 1920s, mandates and responsibilities were re-organized with a clear separation of military and civilian responsibilities principally between the Department of National Defence and the Department of the Interior. However, the Canadian Air Force arm of DND frequently provided flying services for both military and civilian aerial photography for years to come (Narraway 1924, Thomas 1950).

Secondary sources of early Canadian aeronautical and photographic achievements at a national scale consist of monographs and learned journal articles. Historical accounts, technical evaluations and thematic studies include those by Kealy and Russell (1965), Thompson (1969, 1975), Hitchins (1972), McAndrew (1981), Shaw (2001), Cronin (2007), Dyce (2013), and Banks (2015). Wheeler and Lambart (1923), Wilson (1924), Parminter (1985), and Smith (1997) assessed activities for western Canada. There are only few details of early air photo missions for eastern Canada. Wilson (1924) provided examples for uses in forestry and hydrology in Quebec during the 1920s. Werle (2016) re-assembled and interpreted air photos of a 1921 mission over the city of Halifax in Nova Scotia and pointed at 
the utility of these images for historical urban studies and detailed change analyses.

Giordano and Mallet (2019), as well as Collier et al. (2001), have emphasized the need to systematically compile information on archives with historical air photo collections in order to support scientific studies. For many locales in North America and Europe, vertical air photo coverage for change analysis goes back to the 1950s; fewer examples are openly available for the World War II decade because of security concerns. Although their operational use in surveying and mapping emerged during the 1930s, there are only rare cases where the historical value and cultural-technological significance of aerial photography between the two wars has been explored (Weems 2011).

As an early adopter of air photo technology, Canada is in a fortunate situation of having archived and curated collections. Next to NAPL, which was established in 1925, municipal and university archives also contain sets of individual air photos going back to the 1920s and 1930s. In the past, it was a common practice to produce air photo mosaics that show the ensemble of vertical photography resulting from a particular survey mission. Examples include reproductions and digital re-assemblies of mosaics for the cities of Halifax, NS (1921), Calgary, AB (1924), Edmonton, AB (1925), Hamilton, ON (1927), the Municipality of Richmond, BC (1935), and the Kitchener-Waterloo area in Ontario (1945).

Apart from post-World War I vertical aerial photography, collections of high-quality survey photographs from mountaintops in the Rocky Mountains of western Canada go back to the late nineteenth and early twentieth century (MacLaren 2005). These oblique photographs of alpine topography have attracted attention from researchers studying land cover change on an unusual centenary time scale. They have examined and compared the old photography with recent photography taken from the same location and depicting the same locales in a quasi-panoramic way (Fortin et al. 2018). In a similar vein, vertical aerial photographs of coastal areas in the Maritimes from the 1920s may lend themselves well as an early photographic benchmark for coastal mapping and monitoring studies with a focus on areas that have a high sensitivity to sea-level rise (Taylor et al. 2014). 


\section{RESULTS}

The archival searches and literature analyses yielded numerous results. During the early 1920s, approximately 1500 high-resolution air photos were collected during seven experimental missions in Nova Scotia and New Brunswick (Fig 1, Table 1). They include coverage of Halifax (1921), the St. Croix River at St. Stephen and Calais (1921), sections of the Northumberland Shore (1923) and Pictou County (1923-24), the Fredericton area (1924-25), the Yarmouth area (1925), and a section of Hants County in Nova Scotia between Walton and Windsor (1925). Excerpts of individual air photos and corresponding recent high-resolution satellite imagery are contained in Fig 2. The National Air Photo Library is engaged in a multi-year project to digitize its holdings of early Canadian aerial photography for access through Canada's Earth Observation Data Management System (EODMS). This process has resulted in indexing the majority of vertical and oblique aerial photography missions of the Maritimes for online queries. The missions have retained their original letter designation "K" or "KA" for the respective mission film rolls. Far less encompassing in coverage compared to NAPL, major Canadian university map libraries as well as provincial archives contain

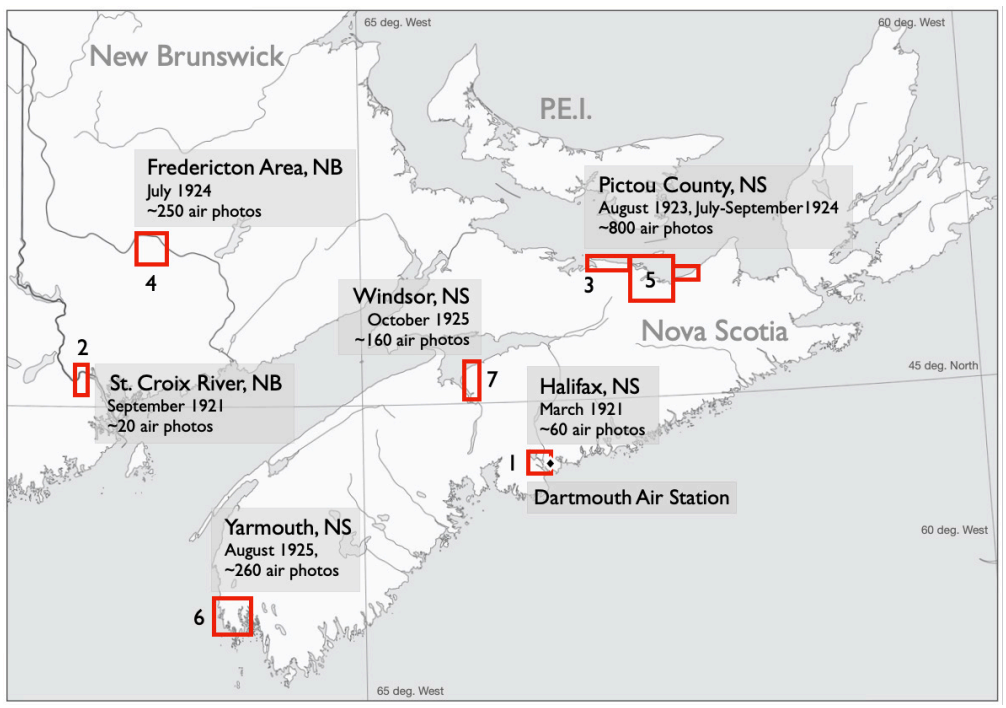

Fig 1 Location map of early vertical air photo survey missions in the Maritimes, 1921-1925. 

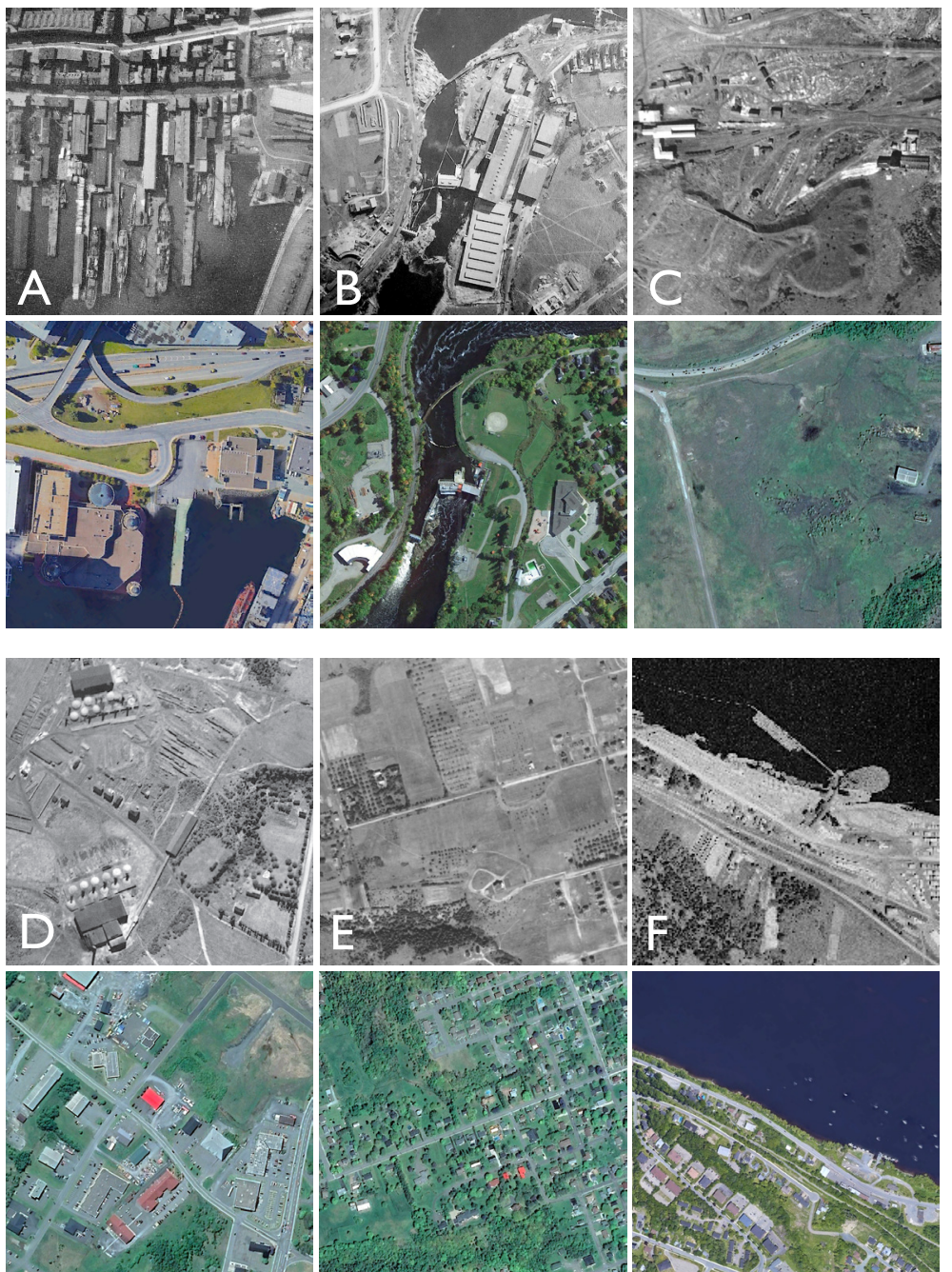

Fig 2 Comparison of $500 \mathrm{~m}$ by $500 \mathrm{~m}$ excerpts of selected early 1920 s blackand-white aerial photography with modern high-resolution, natural colour satellite imagery of the same locale: (A) finger-piers on the Halifax waterfront (1921); (B) cotton mill and timber rafts on the St. Croix River (1921); (C) coal mining operations, (D) clay mining and kiln operations, and (E) orchards in Pictou County (1923, 1924); and (F) Victoria lumber mill along the Saint John River near Fredericton (1925). Source: Air photos courtesy of NAPL; satellite imagery courtesy of Google Earth. 

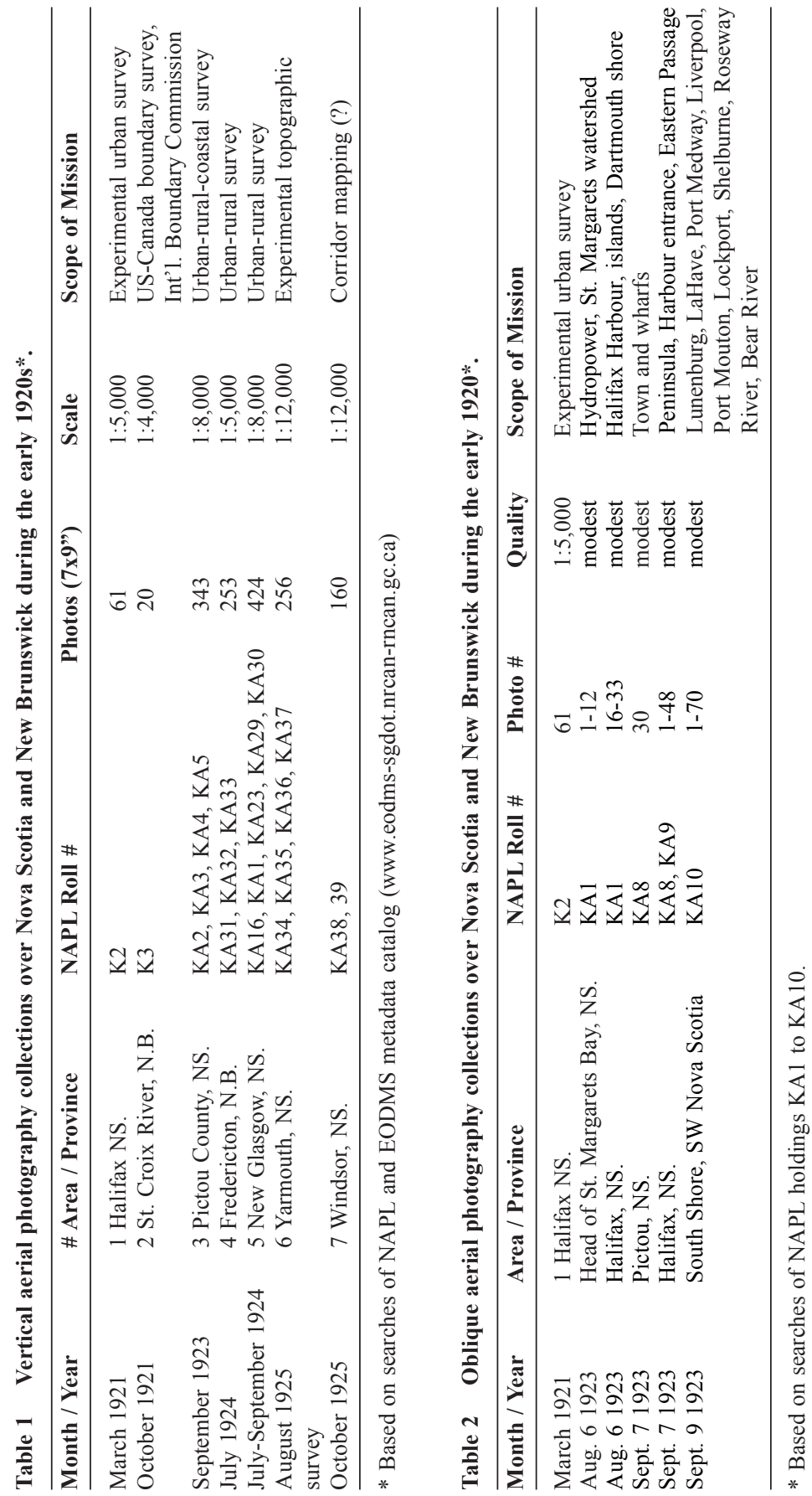
select regional sets of 1920 s and 1930 s air photos in either digital or analog format. However, their holdings of coverage for areas in the Maritimes are very sparse.

Next to the vertical air photos, there are also approximately 150 oblique aerial photographs on record dating back to sorties during the late summer and early fall of 1923. These individual rather than serial photos were acquired as a "photographic reconnaissance of coastline" and water resource assessments, as noted in the Canada Air Board report for that year (CAB 1923). The NAPL has copies of modest quality for some of these photos in its holdings, but there is no record of them on the EODMS. NAPL rolls KA1 and KA7 to KA10 contain low oblique imagery of the Halifax Harbour area, Pictou, Lunenburg (Fig 3), LaHave, Port Medway, Liverpool, Port Mouton, Lockport and Shelburne of Nova Scotia, and of the city of Saint John in New Brunswick. Several oblique photos were collected over the Head of St. Margarets Bay, and the Roseway, Bear and Musquash rivers (Table 2). The potential use of the oblique air photos may be limited to interpretative studies and comparison with more recent and systematic oblique videography of Nova Scotia's coastline acquired for scientific work (Taylor et al. 2014).

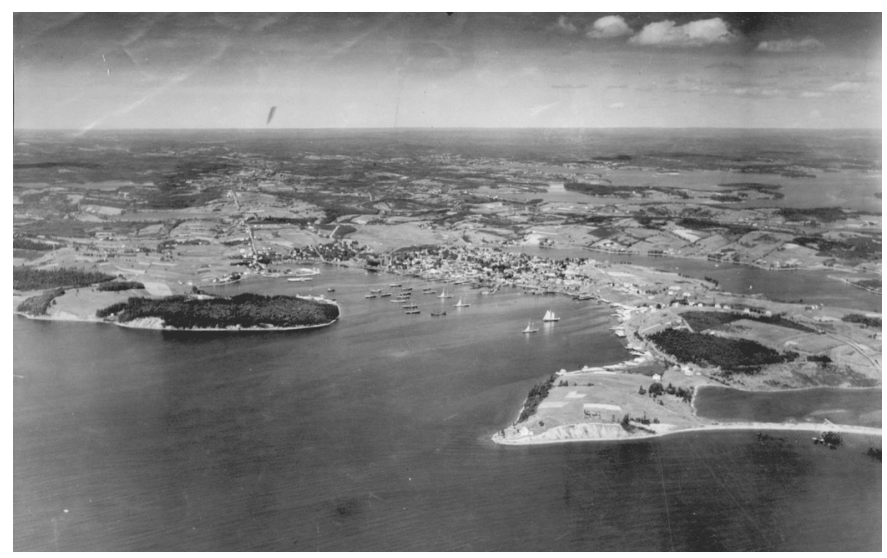

Fig 3 Example of low-oblique aerial photography collected over selected areas along the South Shore of Nova Scotia; Lunenburg Harbour, September 9, 1923. Source: Air photo courtesy of NAPL, Roll KA10-002. 

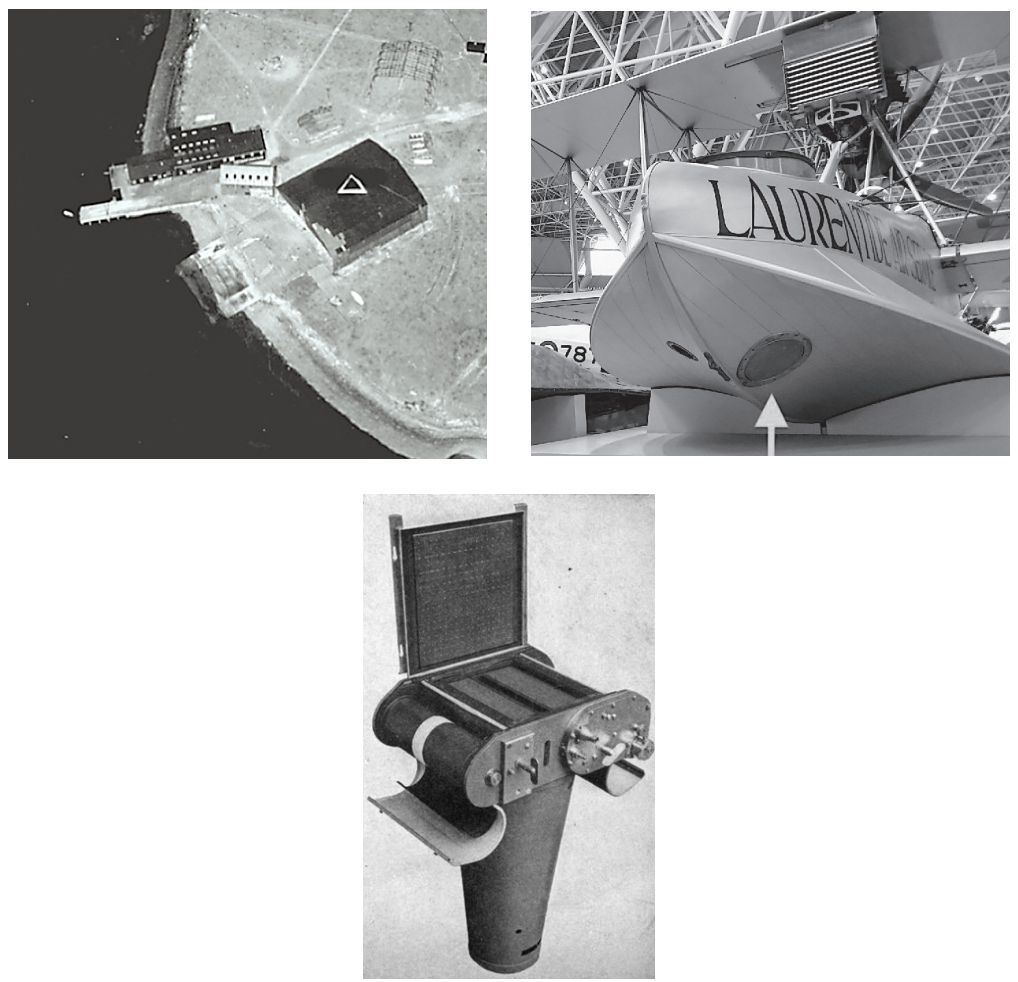

Fig 4 High-oblique aerial photograph of the Dartmouth Air Station at Baker Point in 1923 (top left), depicting the main $30 \mathrm{~m}$ by $30 \mathrm{~m}$ large hangar, slipway for launching flying boats, scaffolding of a WW-1 vintage Bessenneau hangar, and an older fish plant buildings and wharf; Curtiss HS-2L flying boat (top right) with air photo camera bay indicated by arrow; and K-type aerial camera (bottom). Source: Air photo courtesy of NAPL, Roll KA9-7, 7.9.1923; HS-2L photo by D. Werle; K-type camera photo courtesy of Ives (1920, Fig. 65).

\section{The Air Station at Baker's Point in Dartmouth}

For the aerial survey activities during the early 1920s, the Air Station at Baker's Point in Dartmouth, Nova Scotia, served as a logistical centre and operational base (Fig 4). The station was originally established in 1918 by the United States Naval Air Service for seaplane patrols along the Atlantic coast to counter the German U-boat threat (Orr 2018, Boileau 2016, Halliday 1987). Following the establishment of the Canada Air Board by the Government of Canada in late 1919, the Baker's Point seaplane base became part of a country-wide network of six main air stations. During these 
formative years, the station operated year-round as one of two designated aircraft maintenance facilities for a small fleet of 12 Curtiss HS-2L sea planes that the US Navy had deeded over to Canada after World War I. Combined with the allocation of trained ground personnel and veteran pilots, the Air Station at Baker's Point supported some of the earliest aerial survey work in the country (Canadian Air Board 1921).

At least two of the HS-2L aircraft, G-CYAC and G-CYAH, were equipped with air photo camera fittings to accommodate the new K-2 and K-3 cameras developed by the Fairchild company in the United States (Fig 4). These cameras included a roll-film magazine with the capacity of exposing up to one hundred 7" by 9" air photos per roll (Sanders 1944). The HS-2L aircraft could nominally fly for four hours at a modest cruising speed of $70 \mathrm{mph}$, enabling air photo missions over parts of mainland Nova Scotia and southern New Brunswick (Terry 2004, Anonymous 1919).

Station activities and flying operations were recorded in weekly reports submitted by the Commanding Officer to the Air Board in Ottawa. Squadron Leader A.B. Shearer, a veteran flier, served as the first commanding officer of the Dartmouth Station and as pilot of several air photo missions. His report for the month of March 1921 mentioned air photo collection for the Halifax mosaic on March 11 (Fig 5, top). Incidentally, there is no entry of this pioneering aerial survey in the official annual Air Board report for that year (Canada Air Board 1921), although on-site inspection reveals that an uncatalogued print set of the actual air photos was deposited at NAPL; the physical flight index map for early aerial photography of Halifax at NAPL contains a handwritten note that the original film was destroyed.

\section{Experimental Air Photo Missions during the early 1920s (1921-1925)}

The operating parameters of the Curtiss HS-2L aircraft, its relatively low flight altitude, and the 12-inch focal length of the survey cameras had notable implications for the scale of the aerial photography of the early 1920s. It varied between 1:5,000 and 1:10,000 (Table 1). Although this apparent limitation precluded large area coverage, the photographs reveal excellent spatial detail on the order of several tens of centimeters, depending on the quality of the original film, film duplicate, paper print, and resolution of the digital 

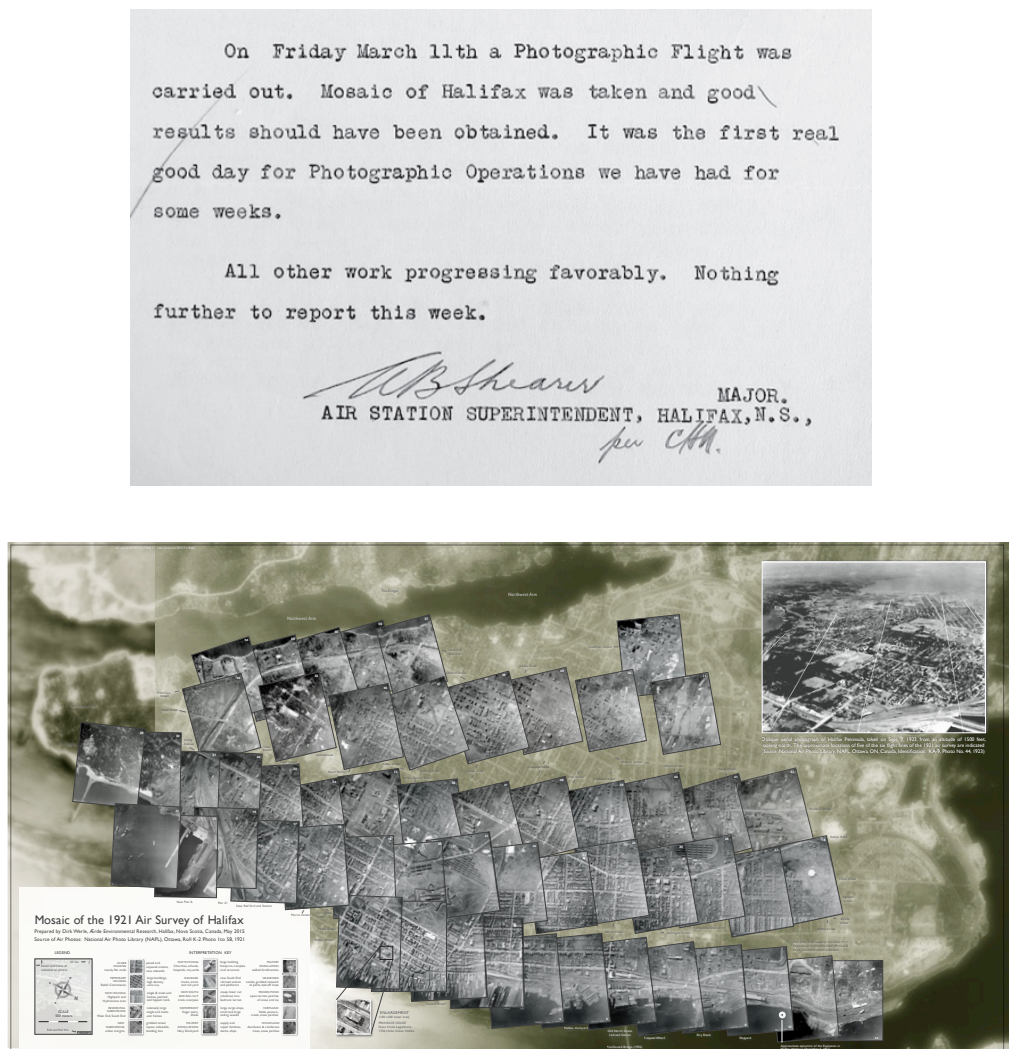

Fig 5 Excerpt of the Dartmouth Air Station "Weekly Report, ending Sunday March 13, 1921" (top) by Major A. B. Shearer, noting photographic operations for the Halifax air photo mosaic (bottom). Source: Shearwater Aviation Museum Library, Dartmouth, NS.; reproduction courtesy of J.L. Orr, June 2018; mosaic by Werle (2016).

reproduction. In principle, the detail matches that of modern highresolution satellite imagery and enables change detection analyses at a rare temporal scale approaching 100 years. All of these surveys were explicitly carried out for civilian purposes.

Halifax survey, 1921. The aerial survey of the city of Halifax on March 11, 1921, is one of the earliest in the country. The survey was clearly experimental and likely initiated for urban planning purposes. The 60 photographs cover the built-up area of the Halifax peninsula in five partially overlapping flight lines (Table 1, Fig 2, Fig 5). This rare portrayal of a post-World War I cityscape reveals a series of infrastructure improvement projects. They include old and 
completely new harbour facilities, new or extended transportation networks and urban designs, while still marking the aftermaths of the catastrophic explosion in Halifax Harbour of December, 1917. A digital mosaic and annotation of the Halifax survey was prepared by Werle (2016).

St. Croix River boundary survey, 1921. Conducted on behalf of the International Boundary Commission to assist in boundary delineation, the St. Croix River boundary survey of October, 1921, is a comparatively small one. It consists of two short overlapping flight lines of 20 photographs covering the course of the river between Milltown, St. Stephen and Calais (Werle 2019b). The density of industrial facilities, on both sides of the US-Canada border, notably cotton and lumber mills at Milltown (Fig 2), had rendered ongoing boundary delineation difficult. Analysis of the detailed aerial photography contributed to a resolution of the problem. The survey not only represents one of the first applications of this kind, but it also portrays the geospatial ensemble of an historic industrial landscape that has since vanished.

Pictou County survey, 1923-1924. The air photo coverage acquired over large parts of Nova Scotia's Pictou County and the Northumberland Shore during the summer months of 1923 and 1924 is extensive. It consists of approximately 800 individual air photos along nine flight lines, none of which have been assembled to form a cohesive mosaic of the urban, rural and industrial land use. The main focus of the aerial survey at the time was on land use mapping and topographic map updates. The air photos reveal a significant part of the industrial heartland of Nova Scotia as it existed a century ago. Partial mosaics assembled by the author provide a detailed visual account of coal mining activities around the town of Stellarton, including significant environmental side effects in the form of sinkholes over the extensive network of subsurface mine shafts and mined coal seams; other portions of the data set show clay mining and kiln operations and agricultural land use patterns (Fig 2). Several flight lines contain vertical photography with detailed delineations of the shoreline; these reveal significant change as a result of coastal erosion and accretion processes extending over the course of the past century (Fig 6).

Fredericton area survey, 1924. The aerial survey of the Fredericton area of New Brunswick comprises approximately 250 air 

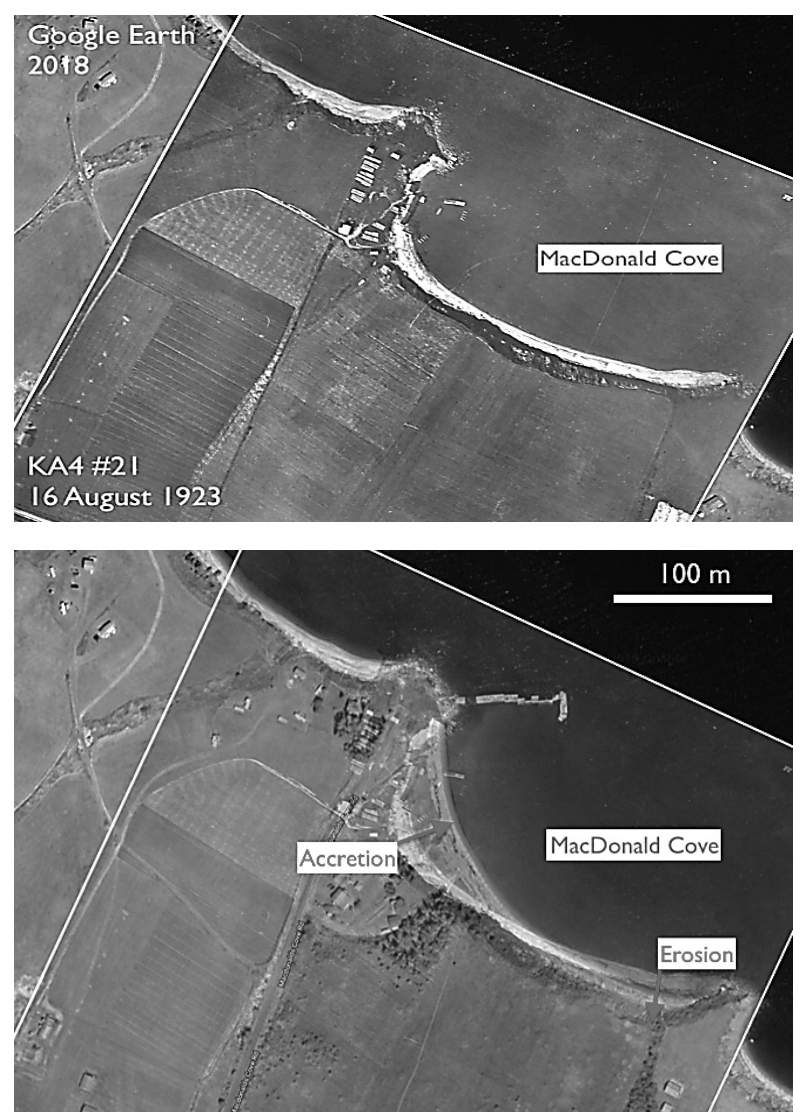

Fig 6 Coastline change over a 95-year period along the Northumberland Shore of Nova Scotia illustrated by co-registration of 1923 aerial photography (top) and 2018 Google Earth satellite imagery (bottom), involving erosion and accretion on the order of several tens of meters within the $300 \mathrm{~m}$ long embayment of MacDonald Cove. Source: Air photo courtesy of NAPL, Roll KA4-21; satellite image courtesy of Google Earth.

photos at a scale of 1:5,000. They cover the eastern portion of the city, parts of the St. John River with logging booms and the Victoria saw-mill operation (Fig 2f), as well as extensive woodlands and agricultural land to the south of the city. The latter portion roughly coincides with the woodland endowment of the University of New Brunswick. Mapping the endowment between the southern outskirts of the city and the settlement of New Maryland may have been the main reason for the survey. A partial mosaic was assembled digitally by the author in 2019 (unpublished). 
Windsor area survey, 1925. The 160 aerial photographs of the Windsor survey of Nova Scotia, in the fall of 1925, cover a narrow North-South corridor between the village of Walton on the Minas Basin and the Avon Peninsula near Windsor, Nova Scotia. The original objective of the survey is unknown. The configuration of the flight lines points toward a corridor mapping exercise. The planners of this survey made a conscientious effort to acquire air photos of high and low tide conditions at Walton (Fig 7).

Yarmouth area surveys, 1925. In August of 1925, a survey over Yarmouth and surrounding coastal areas of southwestern Nova Scotia obtained some 260 vertical air photos. The layout of the four parallel, East-West oriented flight lines suggest that the experiment was geared toward topographic mapping or map updating. The coverage of coastal locales with their frequent changes in reflectance of land and water surfaces posed initial challenges for adjusting exposure settings of the air photos. However, this problem was resolved as shown by an expansion of the survey in subsequent years.

\section{Air Photo Missions during the late 1920s (1927-1931)}

The successful completion of the experimental surveys of the early 1920s set a pattern for topographic mapping activities in the
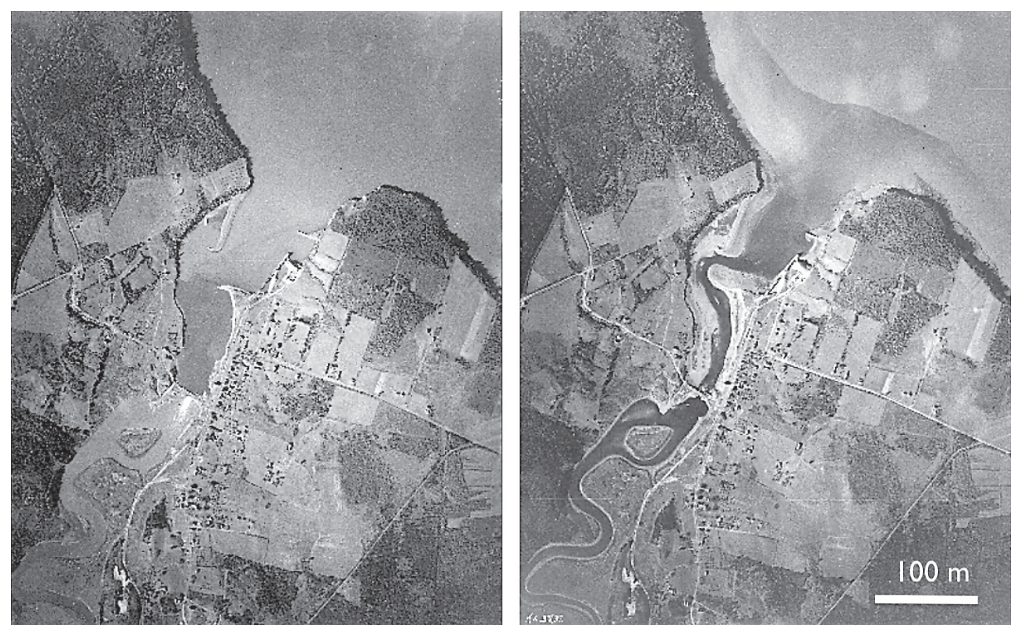

Fig 7 Example of early aerial photography of tidal conditions along the Minas Basin at Walton, NS. captured at high tide on October 18 (left) and low tide on October 19, 1925 (right). Source: Air photos courtesy of NAPL, Roll KA38-3 (left) and KA38-37 (right). 
Maritimes during the latter part of the decade and beyond. The Yarmouth air photo mission of 1925 served indeed as a precursor for a much larger survey of southwestern Nova Scotia by the Topographic Survey Branch of the Department of the Interior. During the summer of 1927, it collected approximately 1400 photos for updating its topographic maps; 10 flight lines cover the Pubnicos, Cape Sable Island, Shelburne and adjacent landward areas with predominantly boggy and sparsely forested terrain. In 1929, more than 80 hours of flying resulted in the collection of additional vertical as well as oblique photographs of western Nova Scotia.

The practice of aerial photography clearly gained momentum during the late 1920s based on the steadily increasing number of missions and their areal extent. The DND records reveal that 25 air photo missions were conducted in the Maritimes between 1927 and 1931 (Table 3); 15 of them covered parts of Nova Scotia and 10 took place in New Brunswick. There is no mention of air photos taken over Prince Edward Island during that time. It appears from the metrics of flying hour and area coverage that a significant number of air photos were acquired over areas in northeastern and southeastern New Brunswick. The total number of air survey related flying hours in the Maritimes amounted to more than 900, increasing steadily from approximately 10 hours in 1927 to 129, 224 and 553 hours in subsequent years. The Topographic Survey carried out more than half of the 25 missions, followed by the Geographic Section of DND with five missions, thus (re-)emerging as a significant user of aerial photographs. Individual surveys were carried out on behalf of interests in national parks, hydrology, forestry and transportation (Table 3). The potential use of these air photos for change detection of coastal areas, wetlands, and estuarine environments is illustrated in Fig 8.

Much of the coverage awaits further assessment in terms of completeness and potential utility for environmental change detection in conjunction with recent imagery. A preliminary inspection of the air photos of the late 1920s and early 1930s suggests that the practice of aerial surveying was evolving and expanding beyond the trials of the early 1920s, as shown in two examples (Table 3). The 1931 survey of the greater Halifax area included the collection of more than 450 air photos at a scale of 1:15,000, exceeding that of the 1921 survey almost by an order of magnitude in terms of air 
Table 3 Vertical and oblique aerial photography collections over Nova Scotia and New Brunswick, 1927-1931 (Source: DND 1929, DND 1930, DND 1931).

\begin{tabular}{cllc}
\hline Year & \# Area, Province* \\
(sqml = square miles) & $\begin{array}{l}\text { Purpose / } \\
\text { Department }\end{array}$ & $\begin{array}{c}\text { FlyingTime } \\
\text { (in hours) }\end{array}$ \\
\hline
\end{tabular}

1927 Southwestern Nova Scotia, NS Topographic Survey/Interior Dept. 10

1928 Newcastle, NB (1820 sqml)

Coastal area, NS

Fredericton area, NB

Chipman area, NB

Nova Scotia interior, NS

1929 Moncton area, NB

Saint John area, NB

Western Nova Scotia

Windsor Reservoir area, NS

Bedford Basin, Halifax, NS

Lake Charlotte area, NS

1931 Newcastle, NB (300 sqml)

Chipman area, NB (200 sqml)

Fort Louisbourg area, NS

Annapolis Valley area, NS

Cambellton, NB (200 sqml)

Topographic Survey / Interior Dept. 112

Geogr. Section / National Defence 5

Topographic Survey / Interior Dept. 4

Topographic Survey / Interior Dept. 2

Topographic Survey / Interior Dept. 6

Shediac area, NB $(117 \mathrm{sqml}){ }^{1}$

Halifax area, NS (920 sqml) ${ }^{2}$

Annapolis V., NS (330 sqml)

Topographic Survey / Interior Dept. 120

Geological Survey / Mines Dept. 8

Topographic Survey / Interior Dept. 80

Topographic Survey / Interior Dept. 5

Geogr. Section / National Defence 8

Topographic Survey / Interior Dept. 3

Bridgewater, NS (1100 sqml) ${ }^{3}$

Coal Fields, NS (225 sqml)

Topographic Survey/Interior Dept. 69

Topographic Survey / Interior Dept 39

National Parks / Interior Dept. 3

Geogr. Section National Defence 5

Topographic Survey / Interior Dept. 24

Topographic Survey / Interior Dept. 13

Geogr. Section National Defence 55

Geogr. Section National Defence 21

Topographic Survey / Interior Dept. 59

Geological Survey / Dept. Mines 45

Hydrological Survey / Marine Dept. 38

Forest Service / Interior Dept. $\quad 94$

Saint John R., NB (corridor)

Sherbrooke area, NS

Highway Dept. / NS Government

8

${ }^{1}$ Coverage of the "Shediac" area survey is contained on NAPL Roll \# 3526, 3527, 3528 and 3529 (335 air photos); NAPL Roll \# 3517 and 3529 contain coverage of the Chignecto Isthmus subset (116 air photos).

2 Coverage of the "Halifax" area is contained on NAPL Roll\# 3522, 3523, 3524 and 3525 (458 air photos).

3 Coverage of the "Bridgewater" area is contained on NAPL Roll\# 3518, 3519, 3520, 3521 and 3530 (509 air photos).

photos taken, and by a hundred-fold in terms of area covered, albeit at smaller scale and lower spatial resolution. The 1931 survey of the Chignecto Isthmus separating the Provinces of New Brunswick and Nova Scotia formed part of a larger "Shediac, N.B." mission that resulted in the overall collection of 450 air photos. Then and now, these low-lying marshes contain critical transportation infrastructure that is increasingly threatened by the effects of climate change and sea level rise. 

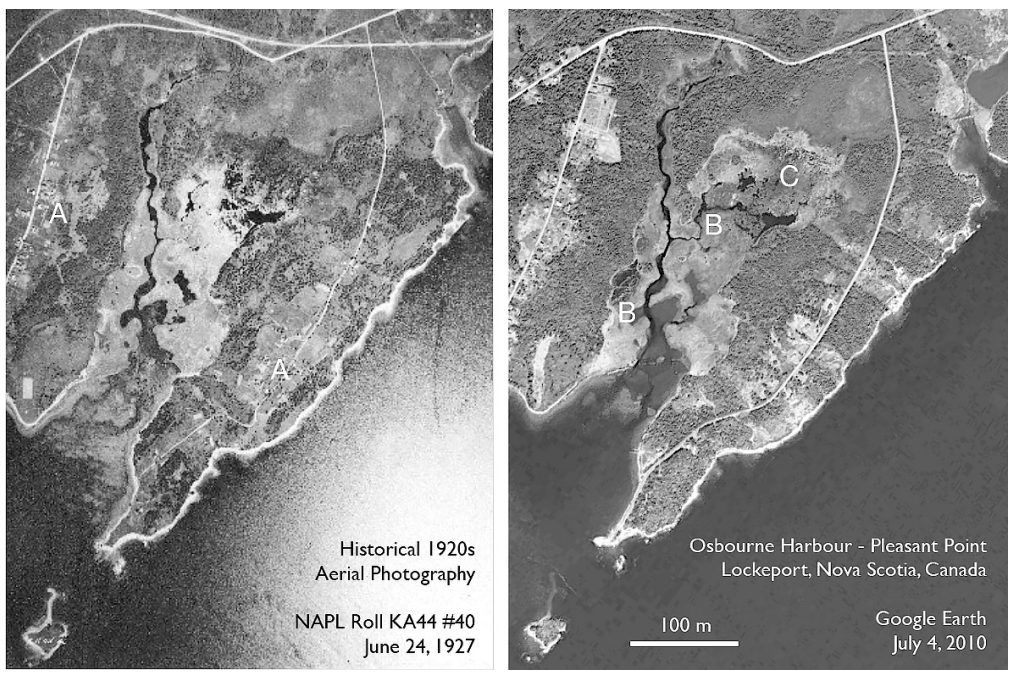

Fig 8 Example of coastal salt marsh changes and influence of sea level rise, as shown by aerial photography taken on June 24, 1927, and Google Earth satellite imagery taken on July 4, 2010, over the Osbourne Harbour Pleasant Point area near Lockeport, NS. In terms of land use, greater areas of pasture (A) appear to prevail in 1927. Given satellite data acquisition during low tide, notable differences between the 1927 and 2010 imagery include slightly larger extent of open waterways and surfaces (B) in the salt marsh area, as well as extension of low marsh vegetation at the head of the salt marsh (C) in 2010, pointing to generally elevated water levels with that zone. Source: Air photo KA44-40 courtesy of NAPL; satellite image courtesy of Google Earth; 2010 tidal data courtesy of Fisheries and Oceans Canada.

\section{DISCUSSION AND CONCLUSION}

In general terms, the adaptation of aerial photography to civilian application during the years immediately following World War I represented a complete turn-around from massive war theatre surveillance and targeting to peaceful experimental use in surveying and mapping. In post-war Canada, political direction and institutionbuilding, combined with enormous mapping and surveying requirements, clearly altered the scope of aerial photography in favour of civilian application. The initial aerial surveys in the Maritimes were guided by the Canada Air Board and its survey committee until the mid 1920s. Nonetheless, the logistical effort was still heavily reliant on veteran personnel for mission planning and surplus war planes for completing the surveys. Vertical air photo collections between 1921 
and 1931 predominantly served the Topographic Survey Branch, Department of the Interior; missions on behalf of the Department of National Defence only started to emerge during the late 1920s.

The study results indicate that the pioneering aerial survey activities in the Maritimes progressed promptly during the early 1920s because of remaining wartime infrastructure and a core of air station personnel at Dartmouth, NS., yielding high-resolution air photos. Today, these largely unnoticed collections are accessible in analog and digital formats at the National Air Photo Library and to a limited extent through university archives. The air photos may have outlived their original purpose to support thematic mapping or map revision at the time. Yet, conception and outcome of the surveying missions deserve to be assessed not only in an historic light but also from contemporary social, historical and environmental science perspectives.

A comparison of the century-old coverage with recent highresolution satellite imagery of selected sites yields insight concerning the usefulness of the historic data sets for present-day investigations and inquiries. This study suggests that the thematic focus could be on land use and land cover, coastal environmental change, transformation of urban, rural and industrial landscapes, as well as educational aspects regarding local and regional heritage. For example, municipal planners, scientists, historians, and the general public stand to benefit from geospatial information derived through analysis of Canada's oldest air photos in conjunction with more recent multi-temporal data layers. Experience to-date with the early 1920s air photos and mosaics in the Maritimes holds promise for examination of the more extensive surveys conducted in the region during the late 1920s. The goal and potential outcome would be three-fold: determine physical location of the actual air photos; exploring quality and geographic extent of the coverage; and tying actual photo content to the analysis of modern geospatial data sets to address present day environmental challenges.

A critical aspect is the digital reconstruction of the individual photographs into cohesive image mosaics for comparison with more recent remotely sensed data sets collected for the purpose of coastal research and mapping. Candidate areas with extensive vertical aerial photography include the Northumberland Shore and the entire southwestern region of Nova Scotia. Likewise, time, 
location and spatial detail of the 116 air photos covering the lowlying marshes of the Chignecto Isthmus could make this so-far unnoticed data set a unique and useful source of geospatial information for assessing long-term land cover, land use changes and environmental risk in light of sea level rise, expectation of severe storm surges and exposure of critical transportation infrastructure.

The air photo collections of the 1920s represent an early legacy of aerial surveying in the Maritime Provinces of Canada. While the actual view-from-above may not capture any historically significant events at the time, detailed coverage of selected areas in Nova Scotia and New Brunswick offers a rare opportunity for geospatial assessments of important natural, cultural and industrial features that are either different or no longer present today. From a scientific perspective, the air photos offer an opportunity for detailed environmental change detection at an unusual centennial time scale when compared with modern imagery. While search and access of individual air photos has become less problematic with the use of online platforms and archives, their ultimate value lies in the composition of image mosaics and thus spatially cohesive reference layers for historical, cultural and scientific inquiries.

Acknowledgements The helpful support received from the National Air Photo Library in Ottawa (Florin Savopol, François Sauvé) and the Shearwater Aviation Museum and Library in Dartmouth (John Orr and Christine Hines) is gratefully acknowledged.

\section{REFERENCES}

Air Board (1921). Report of the Air Board for the year 1920. Thomas Mulvey Printer, Ottawa, ON $16 \mathrm{p}$.

Air Board (1922). Report of the Air Board for the year 1921. F.A. Acland Printer, Ottawa, ON $20 \mathrm{p}$.

Air Board (1923). Report of the Air Board for the year 1922. F.A. Acland Printer, Ottawa, ON 75 p.

Amad, P. (2012). From God's-eye to Camera-eye: Aerial photography's post-humanist and neo-humanist visions of the World. History of Photography 36 (1): 66-86.

Anonymous (1919). The U.S. Navy HS-1L and HS-2L flying boats. Flight, Issue of December 4, 1919: 550-552.

Banks, B. (2015). Drawn from victory. Canadian Geographic October 2015: 45-50. 
Boileau, J. (2016). Byrd at Bakers's Point. Halifax Military Heritage Preservation Society Paper Series, HMHPS Paper No. 3, Halifax, NS, 19 p.

Canadian Air Board (1921). Report on an Experimental Aerial Survey at Ottawa 1920. The Air Board Bulletin No. 2, March 31, 1921: 1-16.

Collier, P., Inkpen, R. \& Fontana, D. (2001). The use of historical photography in environmental studies. Cybergeo: European Journal of Geography journals.openedition.org/cybergeo/4019.

Cronin, M. (2007). Northern visions: Aerial surveying and the Canadian mining industry1919-1928. Technology and Culture 48 (2): 303-330.

Department of National Defence (DND) (1925). Report of the Department of National Defence Canada for the Fiscal Year ending March 1925 (Militia \& Air Services). F.A. Acland, Ottawa, ON 54 p.

Department of National Defence (1929). Report on Civil Aviation and Civil Government Air Operations for the Year 1928. F.A. Acland, Ottawa.

Department of National Defence (1930). Report on Civil Aviation and Civil Government Air Operations for the Year 1929. F.A. Acland, Ottawa.

Department of National Defence (1931). Report on Civil Aviation and Civil Government Air Operations for the Year 1931. F.A. Acland, Ottawa.

Deville, E. (1889). Photographic Surveying, Including the Elements of Descriptive Geometry and Perspective. Ottawa, ON, Canada, Government Printing Bureau 1889, 324 p.

Dorrian, M. \& Pousin, F. (eds.) (2013). Seeing from Above - The Aerial View in Visual Culture. London and New York, I.B. Tauris Ltd., 312 p.

Dyce, M. (2013). Canada between the photograph and the map: Aerial photography, geographical vision and the state. Journal of Historical Geography 29: 69-84.

Elsdale, H. (1884). Balloon photography from small balloons, and its application in war and peace. Extracts from the Proceedings of the Royal Engineer Committee during the year 1883. War Office, London, 1884, Memorandum I (October 18, 1882) Memorandum II (July 26, 1883) and Memorandum III (August 9, 1883), Appendix No. 1: 1-43.

Finnegan, T. J. (2011). Shooting the Front. Allied Aerial Reconnaissance in the First World War. The History Press, Spellmount, Stroud, UK, 408 p.

Fortin, J., Fisher, J.T., Rhemtulla, J.M. \& Higgs, E.S. (2018). Estimates of landscape composition from terrestrial oblique photographs suggest homogenization of Rocky Mountain landscapes over the last century. Remote Sensing in Ecology and Conservation 5 (3): 224-236.

Halliday, H. (1987). Seaplane base - Captured in art. The Atlantic Advocate, Nov. 1987: 6-8.

Hitchins, F.H. (1972). Air Board, Canadian Air Force and Royal Canadian Air Force. Ottawa, ON: Canadian War Museum Paper No. 2, Canadian War Museum, $475 \mathrm{p}$.

Ives, H.E. (1920). Airplane Photography. J.B. Lippincott Company, Philadelphia and London, $422 \mathrm{p}$.

www.gutenberg.org/files/53508/53508-h/53508-h.htm 
Kealy, J.D.F. \& Russell, E.C. (1965). A History of Canadian Naval Aviation 1918-1962. Naval Historical Section, Canadian Forces Headquarters, Department of National Defence, Ottawa, ON, 159 p.

MacAndrew, W.J. (1981). The evolution of Canadian aviation Policy following the First World War. Journal of Canadian Studies 16 (3,4): 86-99.

MacDonald, T.W. (2017). Firsts in Flight - Alexander Graham Bell and his innovative airplanes. Formac, Halifax, NS. 96 p.

MacLaren, I.S. (2005). Mapper of Mountains: M.P. Bridgland and the Canadian Rockies 1902-1930. Edmonton, AB: The University of Alberta Press, 294 p.

Narraway, A.M. (1924). Preliminary report of aerial survey operations season 1924 of the Topographical Survey of Canada in co-operation with the Royal Canadian Air Force National Archives of Canada, R12365-04-E. Volume/box number: 1, MIKAN No. 3783624.

Orr, J.L. (2018). An east coast air station: Shearwater 1918-2018. Canadian Naval Review 14 (1): 13-18.

Parminter, J. (1986). Guardians in the sky: Aircraft and their use in forestry in B.C. 1918-1926. Whistle Punk - B.C. Forest History Magazine 1 (4): 3-10.

Payne, S.R. (1999). A History of the Rockcliffe Airport Site: Home of the National Aviation Museum. Ottawa, ON: National Aviation Museum, $39 \mathrm{p}$.

Saint-Amour, P. (2013). Photomosaics: Mapping the front, mapping the cities. Chapter 5 in: Adey, P., Whitehead, M., and Williams, A. (eds.) From Above: War, Violence, and Verticality, New York, NY: Hurst Publishers, $356 \mathrm{p}$.

Sanders, R.G. (1944). Aerial cameras and photogrammetric equipment: A quarter century of progress. Photogrammetric Engineering \& Remote Sensing 10 (3): 136-159.

Shaw, S.B. (2001). Photographing Canada from Flying Canoes. Burnstown, ON: GSPH, 301 p.

Smith, D. (1997). Those magnificent men and their flying machines: Aerial reconnaissance in the Alberta Rocky Mountains during the 1920s. Western Geography 7: 73-96.

Taylor, R.B., Forbes, D.L. Frobel. D., Manson, G.K. \& Shaw, J. (2014). Coastal geoscience studies at the Bedford Institute of Oceanography, 1962-2012. Chapter 23 in: Voyage of Discovery: Fifty Years of Marine Research at Canada's Bedford Institute of Oceanography. (Eds. D.N. Nettleship, D.C. Gordon, C.F.M. Lewis, M.P. Latremouille) BIO Oceans Association: 203-210.

Terry, C. (2004). Anti-submarine warfare pioneer to bush pioneer: The HS2L in Canada. Canada Aviation Museum Photo Essay, Ottawa, ON, 10 p.

Thomas, R.I. (1950). Photographic operations of the Royal Canadian Air Force. Arctic 3 (3): 150-165.

Thomson, D.W. (1969). Men and Meridians: The History of Surveying and Mapping in Canada, Volume 3, 1917 to 1947. Ottawa, ON: Department of Energy, Mines and Resources, 370 p. 
Thomson, D.W. (1975). Skyview Canada: A Story of Aerial Photography in Canada. Ottawa, ON: Department of Energy, Mines and Resources, 270 p. Weems, J. (2011). Images, technology, and history. Interpreting a 1930s aerial survey photograph: the artfulness of technological images. History and Technology 27 (2): 223-231.

Werle, D. (2016). Early aerial photography and contributions to Digital Earth - The case of the 1921 Halifax air survey mission in Canada. IOP Conference Series: Earth and Environmental Sciences 34: 1-8.

Werle, D. (2019a). Tinker, mapper, soldier, spy - Captain Henry Elsdale's pioneering 1882-83 experiment with small balloons and vertical aerial photography in Halifax. Canadian Journal of Remote Sensing 45 (5): 603-617.

Werle, D. (2019b). Good air photos make good neighbours - A pioneering 1921 aerial survey over the Calais and St. Stephen area in support of US-Canada boundary delineation along the St. Croix River. Proceedings of the $40^{\text {th }}$ Canadian Symposium on Remote Sensing, Fredericton, NB, extended abstract, 2 p. + air photo mosaic.

Wheeler, A.O. \& Lambart, H.F. (1923). Mountain reconnaissance by airplane. The Canadian Alpine Journal 13: 146-157.

Wilson, E. (1924). The use of the aeroplane in surveying and engineering. The Engineering Journal VII: 3-7. 
